\title{
M athematical model for determining the design parameters of an inflatable payload-bearing space platform
}

Institute of Technical Mechanics

of the National Academy of Sciences of $U$ kraine and the State Space Agency of U kraine

15 Leshko-Popel St., D nipro 49600, Ukraine; e-mail: ericksaavedralim@ gmail.com

\begin{abstract}
The development and application of inflatable space structures is of considerable interest in modern space science and technology. Today, these structures enjoy wide application from aerodynamic inflatable deorbit means to inflatable residential sections for the International Space Station. This is because the masses of inflatable structures are smaller in comparison with others, which in turn minimizes the cost of their orbital injection. In view of the considerable interest in orbital constellations, the authors of this article propose the use of an inflatable space aerodynamic system as a platform for a payload. In doing so, we obtain a distributed satellite system on an inflatable space platform. The advantage of this technology is that it assures the maintenance of the relative position of the elements (payload) of a distributed satellite system of this type with minimal energy consumption.

In its turn, to analyze the features of the operation of a particular space technology, its mathematical model is required. Because if this, the aim of the article is to develop a mathematical model for estimating the design parameters of an inflatable payload-bearing space platform.

The mathematical model of the operation of an inflatable payload-bearing space platform developed in this work consists of three modules: a module of orbital motion, a module of calculation of the thermodynamic parameters of the inflatable platform, and a module of calculation of its variable inertia tensor. The article also identifies four gas modes of operation of the inflatable segment of the space platform and gives the inertia tensor as a function of the ambient temperature, which is necessary for further research. It should be noted that the application of the mathematical model allows a priori analysis of a wide range of inflatable space platform design parameters. On this basis, a design parameter analysis method that uses this model was developed. The application of this method may greatly simplify further research into the synthesis of an angular motion controller for an inflatable payload-bearing space platform, the choice of the design parameters of inflatable segment shell materials, and the study of the platform operation in different gas modes.
\end{abstract}

Keywords inflatable space platform, payload, mathematical model, design parameters, thermodynamic parameters.

1. Curzi G., Modenini D., Tortora P. Large constellations of small satellites: A survey of near future challenges and missions. Aerospace 2020. V. 7. No. 133. doi:10.3390/aerospace7090133.

https://doi.org/10.3390/aerospace7090133

2. IADC Statement on Large Constellations of Satellites in Low Earth Orbit. Issued by IADC Steering Group and Working Group 4. IADC-15-03 July 2021. URL: https://www.iadc-

home.org/documents_public/view/id/174\#u (last accessed on November 14, 2021).

3. Ukrainian Patent for Invention No. 117381, IPC B 64 G 1/62, B 64 G 1/10. Method and spacecraft for the orbital injection and deorbit of nano- and picosatellite constellations / Alpatov A. P., Palii O. S. Skorik O. D. - a201604541 ; filed on April 25, 2016 ; published on July 25, 2018, Bul. No. 14. (in Ukrainian).

4. The Echo-I inflation system. Langley research center ; chief D. L. Clemmons Jr. Hampton, Virginia, 1964. 56 p. No. TN D-2194.

5. Kucheiko A. Misty: invisible satellites in space. Novosti Kosmonavtiki. 2004. V. 14. No. 6. Pp. 50 53. (in Russian).

6. US Patent for Invention No. 5345238, IPC H 1 Q 15/16. Satellite signature suppression shield. M. T. Eldridge, K. H. VcKechnie, R. M. Helfey. 494278 ; filed on March 14, 1990; published on September 6, 1994. 
7. Babuscia A., Knapp M., Hicks F. M. et al. InCUBEation : A series of mission for interplanetary exploration using small satellite platforms. Presentation A.1.3 on Interplanetary Small Satellite Conference, 20-21 June 2013 California Institute of Technology, Pasadena, California. URL: http://www.intersmallsatconference.org (last accessed on November 14, 2021).

8. Lichodziejewski D., Veal G., Helms R., Freeland R., Kruer M. Inflatable Rigidizable solar array for small satellites. In: Proceedings of 44th AIAA/ASME/ASCE/AHS/ASC Structures, Structural Dynamics, and Materials Conference. AIAA-2003.98. URL: https://doi.org/10.2514/6.2003-1898.

https://doi.org/10.2514/6.2003-1898

9. R. E. Freeland, S. Bard, G. R. Veal G. D. Bilyeu et al. Inflatable antenna technology with preliminary shuttle experiment results and potential applications. URL:

https://trs.jpl.nasa.gov/bitstream/handle/2014/26491/96-1367.pdf?sequence=1 (last accessed on November 14, 2021).

10. Graybeal N. W., Craig J. I., Whorton M. S. Deployment modeling of an inflatable solar sail spacecraft. Presented at the AMA Guidance, Navigation and Controls Conference, Keystone Colorado, August 21-24, 2006. Paper AIAA 2006-6336. URL:

https://smartech.gatech.edu/bitstream/handle/1853/34446/e-16-y34_10127.pdf (last accessed on November 14, 2021).

11. Schenk M., Viquerat A. D., Seffen K. A., Guest S. D. Review of inflatable booms for deployable space structures: Packing and rigidization. Journal of Spacecraft and Rockets. V. 51. No. 3. URL: https://arc.aiaa.org/doi/10.2514/1.A32598 (last accessed on November 14, 2021). https://doi.org/10.2514/1.A32598

12. Curtis H. Orbital Mechanics for Engineering Students (4th Edition). Butterworth-Heinemann, 2019. 692pp.

13. Fortescue P., Stark J., Swinerd G. Spacecraft Systems Engineering. Chichester: John Wiley \& Sons Ltd., 2011. 724 pp. https://doi.org/10.1002/9781119971009

14. Alpatov A., Kravets Vic., Kravets Vol., Lapkhanov E. Representation of the kinematics of the natural trihedral of a spiral-helix trajectory by quaternion matrices. Transactions on Machine Learning and Artificial Intelligence. 2021. V. 9. No. 4. Pp. 18-29.

https://doi.org/10.14738/tmlai.94.10523

15. Chelnokov Yu. N. Quaternion and Biquaternion Models and Methods of Mechanics of Rigid Body and their Applications. Motion Geometry and Kinematics. Moscow: FIZMATLIT, 2006. 512 pp. (in Russian).

16. Duboshin G. N.. Celestial Mechanics. Basic methods and Problems. Moscow: Nauka, 1968. 800 pp. (in Russian).

17. Maslova A. I.., Pirozhenko A. V. Orbit changes under the small constant deceleration. Kosm Nauka Tehnol. . 2016. V. 22. No. Pp. 20 - 24. (in Russian). https://doi.org/10.15407/knit2016.06.020 
18. Pirozhenko A. V., Maslova A. I., Vasilyev V. V. About the influence of second zonal harmonic on the motion of satellite in almost circular orbits. Space Sci. \& Technol. 2019. V. 25. No. 2. Pp. 3 - 11. (in Russian). https://doi.org/10.15407/knit2019.02.003

19. Mirer S. A. Space Flight Mechanics. Orbital Motion. Moscow: Rezolit, 2007. 270 pp. (in Russian).

20. Golubek A., Dron' M., Dubovik L., Dreus A., Kulyk O., Khorolskiy P. Development of the combined method to de-orbit space objects using an electric rocket propulsion system. Eastern-European Journal of Enterprise Technologies. 2020. V. 4. No. 5(106). p. 78-87.

https://doi.org/10.15587/1729-4061.2020.210378

21. Lapkhanov E., Khoroshylov S. Development of the aeromagnetic space debris deorbiting system. Eastern-European Journal of Enterprise Technologies. 2019. V. 5. No. 5(101). Pp. 30 - 37. https://doi.org/10.15587/1729-4061.2019.179382

22. Khramov D. A. Visual modelling spacecraft motion. Teh. Meh. 2015. No. 2. Pp. 49 - 58. (in Russian).

23. Martinez I. Spacecraft thermal modelling and testing. 43 pp. URL:

http://webserver.dmt.upm.es/ isidoro/tc3/Spacecraft\%20Thermal\%20Modelling\%20and\%20Testing.pd $f$ (last accessed on November 14, 2021).

24. Horn A. C. A Low Cost Inflatable CubeSat Drag Brake Utilizing Sublimation. 2017. DOI: 10.25777/1xaw-be17. URL:

https://digitalcommons.odu.edu/cgi/viewcontent.cgi?article=1028\&context=mae_etds (last accessed on November 14, 2021). 